\title{
Influence of the Medium Composition and the Culture Conditions on Surfactin Biosynthesis by a Native Bacillus subtilis natto BS19 Strain
}

\author{
Beata Koim-Puchowska (D), Grzegorz Kłosowski *(D), Joanna Maria Dróżdż-Afelt (D), Dawid Mikulski \\ and Alicja Zielińska
}

check for updates

Citation: Koim-Puchowska, B.; Kłosowski, G.; Dróżdż-Afelt, J.M.; Mikulski, D.; Zielińska, A. Influence of the Medium Composition and the Culture Conditions on Surfactin Biosynthesis by a Native Bacillus subtilis natto BS19 Strain. Molecules 2021, 26, 2985. https://doi.org/ $10.3390 /$ molecules 26102985

Academic Editors:

Łukasz Chrzanowski,

András Táncsics and

Łukasz Ławniczak

Received: 23 April 2021

Accepted: 14 May 2021

Published: 18 May 2021

Publisher's Note: MDPI stays neutral with regard to jurisdictional claims in published maps and institutional affiliations.

Copyright: (c) 2021 by the authors. Licensee MDPI, Basel, Switzerland. This article is an open access article distributed under the terms and conditions of the Creative Commons Attribution (CC BY) license (https:// creativecommons.org/licenses/by/ $4.0 /)$.
Department of Biotechnology, Kazimierz Wielki University, K.J. Poniatowski St12, 85-671 Bydgoszcz, Poland; koimpuch@ukw.edu.pl (B.K.-P.); jdrozdz@ukw.edu.pl (J.M.D.-A.); dawidmikulski@ukw.edu.pl (D.M.); alicja.zielinska@student.ukw.edu.pl (A.Z.)

* Correspondence: klosowski@ukw.edu.pl

\begin{abstract}
An effective microbial synthesis of surfactin depends on the composition of the culture medium, the culture conditions and the genetic potential of the producer strain. The aim of this study was to evaluate the suitability of various medium components for the surfactin producing strain and to determine the impact of the culture conditions on the biosynthesis of surfactin isoforms by the newly isolated native strain Bacillus subtilis natto BS19. The efficiency of surfactin biosynthesis was determined by measuring the surface tension of the medium before and after submerged culture $(\mathrm{SmF})$ and by qualitative and quantitative analysis of the obtained compound by high performance liquid chromatography. The highest efficiency of surfactin biosynthesis was achieved using starch as the carbon source and yeast extract as the nitrogen source at $\mathrm{pH} 7.0$ and $37^{\circ} \mathrm{C}$. Potato peelings were selected as an effective waste substrate. It was shown that the increase in the percentage of peel extract in the culture medium enhanced the biosynthesis of surfactin $(\mathrm{mg} / \mathrm{L})(2-30.9 \%$; $4-46.0 \%$ and $6-58.2 \%$ ), while reducing surface tension of the medium by about $50 \%$. The obtained results constitute a promising basis for further research on biosynthesis of surfactin using potato peelings as a cheap alternative to synthetic medium components.
\end{abstract}

Keywords: surfactin; Bacillus subtilis; medium components

\section{Introduction}

Surfactin analogs are one of the most effective surfactants. When used at a very low concentration of $20 \mu \mathrm{M}$, they reduce the surface tension of water from 72 to $22 \mathrm{mN} / \mathrm{m}$. Moreover, this compound lowers the interfacial tension in the n-hexane/water system from 43 to $<1 \mathrm{mN} / \mathrm{m}$ [1,2]; hence the wide application of this lipopeptide in many areas, including medicine, environmental protection and agriculture as an alternative to synthetic equivalents [3-7]. The properties of surfactin result from this amphiphilic structure. The surfactin molecule consists of a hydrophilic part, namely, a peptide ring consisting of 7 amino acids (L-glutamine, L-leucine, D-leucine, L-valine, L-asparagine, D-leucine and L-leucine) and a hydrophobic part, namely, $\beta$-hydroxy acid [8]. Microorganisms (mainly Bacillus subtilis strains) produce many isoforms (analogs) of this compound. The isoforms differ in the configuration of amino acids in the peptide ring, and in length (from 10 (C-10) to $16(\mathrm{C}-16))$ and the branching of fatty acid side chains $[9,10]$. Importantly, the differences in the structure of surfactin are reflected in surfactant and foaming properties of this compound [11,12]. The biosynthesis of individual surfactin isoforms and thus the properties of the mixture are determined by the fermentation environment and the type and availability of nutrients $[10,13,14]$. Therefore, although the history of surfactin dates back to 1968, numerous studies are still being carried out on the influence of the composition of the culture medium and the culture conditions on the production of this compound [13,15-19]. 
The temperature of $B$. subtilis cultures producing surfactin ranges over quite a wide interval: from 25 to $37^{\circ} \mathrm{C}$ [20]. The microbiological synthesis of this compound was also confirmed in the cultures incubated at temperatures higher than $40{ }^{\circ} \mathrm{C}$ [21]. The culture medium $\mathrm{pH}$ significantly changes the metabolism of microorganisms (including the transport of compounds through the cell membrane), and affects the intensity of surfactin production. It was shown that the neutral $\mathrm{pH}$ of the medium promoted the synthesis of surfactin [22,23]. Bacillus spp. strains prefer water-soluble nutrients; on the other hand, hydrophobic hydrocarbons can even lead to inhibition of surfactin synthesis $[13,24,25]$. Additionally, this choice is supported by the lower cost of the water-soluble medium components $[5,24,26]$. The source of carbon in synthetic media is mainly glucose, but also fructose, sucrose, maltose or soluble starch, which are preferred to glycerol or hexadecane $[16,21,25,27]$. Cooper's mineral medium, along with Landy's, is one of the most widely used culture mediums for surfactin biosynthesis and the basis for modifying the nutrient ratio $[28,29]$. This medium contains glucose ( $40 \mathrm{~g} / \mathrm{L})$ as a carbon source [13]. As it turns out, the choice of the carbon source is not the only significant influence on the biosynthesis of surfactin, the concentration of the substrate used is also important. A glucose concentration that is too high $(60-80 \mathrm{mg} / \mathrm{L})$ lowers the $\mathrm{pH}$ of the medium and thus inhibits the production of this biosurfactant [30]. At elevated glucose concentrations, bacterial cells probably do not show physiological adaptation to the biosynthesis of surfactants [27]. For the production of surfactin by Bacillus spp., the aforementioned Cooper's medium and Landy's medium are used, with two different nitrogen sources: ammonium nitrate and glutamic acid, respectively [29]. Ammonium chloride, ammonium nitrate, ammonium sulfate, ammonium ferric citrate, potassium nitrate, sodium nitrate, yeast and beef extract, peptone and tryptone are also used as nitrogen sources [21,31,32]. The study by Das and Mukherjee [21] on B. subtilis DM-03 and DM-04 strains demonstrated the importance of the proper selection of nitrogen source for surfactin biosynthesis. They showed that in media poor in nitrogen, surfactin with reduced surfactant properties may be produced. Moreover, the two tested strains differed in their nitrogen source preferences. Ammonium nitrate turned out to be better for the DM-03 strain, while tryptone was better for DM-04. On the other hand, Ghribi and Ellouze-Chaabouni [27] showed that among the organic nitrogen sources (urea, pancreatic casein extract, beef extract, yeast extract) used for the synthesis of biosurfactants by the Bacillus subtilis SPT1 strain, urea was the most effective $(750 \mathrm{mg} / \mathrm{L}$ of biosurfactants using $5 \mathrm{~g} / \mathrm{L}$ of urea).

The high cost of the medium components prompted researchers to analyze waste products as substrates for Bacillus spp. cultures. The use of waste, in particular waste from agri-food processing, as substrates for the production of biologically active compounds is a rational way of managing substances that may pose a threat to the environment. At the same time, this solution allows reduction of the production costs of biodegradable surfactants, and thus makes them more affordable. Assessing the suitability of a substrate is an important part of the feasibility study of a biotechnological process. The components contained in the waste must guarantee the proper development of microorganisms and efficient synthesis of biosurfactants, and at the same time, the disposal of residues should not pollute the environment. Therefore, waste with a high carbohydrate or fat content is still being sought (Makkar and Cameotra [33]) that can replace synthetic sources of carbon and nitrogen, and at the same time contain essential minerals. So far, the following waste products have been used to produce biosurfactants synthesized by various strains of Bacillus spp.: molasses [32,34]; potato, orange and banana peel extract; whey [3 2]; soy flour and rice straw [35]; cassava wastewater [24]; and cashew juice [36]. It should be emphasized that the efficiency of waste substrates is determined by the metabolic abilities of individual strains and the conditions of the surfactin biosynthesis process.

The aim of the study was to analyze the effect of modifications of the Cooper's medium composition (carbon source, nitrogen source) on the biosynthesis of surfactin (amount and percentage of individual isoforms) produced by the native strain of $B$. subtilis natto BS19. We assessed the growth rate of cell biomass in modified media and the reduction 
of the surface tension of the medium at various temperature and $\mathrm{pH}$ conditions. After verification and analysis of the usefulness of synthetic carbon sources in biosynthesis of various surfactin isoforms, we additionally investigated the possibility of using potato peel extract as an effective and cheaper carbon source for the producer strain.

\section{Results}

\subsection{Synthetic Carbon Sources}

The data presented in Table 1 show that not all of the analyzed carbon sources were assimilated by the native Bacillus subtilis natto BS19 strain. Of the sugars tested, lactose and xylose were not the preferred substrates. A slight increase in biomass was observed in the media containing these sugars (lactose: $0.1 \pm 0.004 \mathrm{mg} / \mathrm{L}$; xylose: $0.05 \pm 0.009 \mathrm{mg} / \mathrm{L}$ ). Surfactin was not produced. Therefore, no reduction in surface tension was observed (xylose) or the surface tension decreased only slightly (lactose). Among the remaining carbon sources, the most intensive surfactin biosynthesis was obtained with the use of soluble starch $(133.38 \pm 4.827 \mathrm{mg} / \mathrm{L})$, although the increase in cell biomass $(1.03 \pm 0.173)$ in this medium was similar to that for other sugars (except for xylose and lactose). Moreover, for starch substrates, the reduction in surface tension was over $70 \%$.

Table 1. Influence of carbon source on the concentration of B. subtilis natto BS19 biomass ( $\mathrm{mg} / \mathrm{mL}$ ), reduction of surface tension (\%) of the medium during the culture and concentration of surfactin $(\mathrm{mg} / \mathrm{mL})$.

\begin{tabular}{cccc}
\hline Source of Carbon & Biomass $(\mathbf{m g} / \mathbf{m L})$ & $\begin{array}{c}\text { Surface Tension Reduction } \\
\mathbf{( \% )}\end{array}$ & $\begin{array}{c}\text { Surfactin } \\
\mathbf{( m g} / \mathbf{L})\end{array}$ \\
\hline Mean $\pm \mathrm{SD}$ & Mean $\pm \mathrm{SD}$ & Mean $\pm \mathrm{SD}$ \\
\hline cellobiose & $1.19_{\mathrm{abcdehij}} \pm 0.02$ & $2.23_{\mathrm{e}} \pm 2.23$ & $0.29_{\mathrm{d}} \pm 0.01$ \\
fructose & $0.68_{\mathrm{abcde}} \pm 0.03$ & $25.06_{\mathrm{dg}} \pm 1.29$ & $4.09_{\mathrm{ad}} \pm 0.34$ \\
galactose & $0.58_{\mathrm{abcdfij}} \pm 0.04$ & $17.30_{\mathrm{c}} \pm 0.78$ & $0.77_{\mathrm{d}} \pm 0.21$ \\
glucose & $0.84_{\mathrm{abcde}} \pm 0.08$ & $29.85_{\mathrm{afgh}} \pm 3.64$ & $8.80_{\mathrm{acd}} \pm 1.34$ \\
glycerine & $1.7_{\mathrm{ace}} \pm 0.90$ & $44.03_{\mathrm{b}} \pm 1.64$ & $3.68_{\mathrm{ad}} \pm 1.81$ \\
lactose & $0.1_{\mathrm{bdf}} \pm 0.00$ & $31.70_{\mathrm{ad}} \pm 1.43$ & $1.17_{\mathrm{d}} \pm 0.92$ \\
maltose & $1.21_{\mathrm{abcde}} \pm 0.10$ & $4.27_{\mathrm{e}} \pm 4.27$ & $0.00_{\mathrm{d}} \pm 0.00$ \\
mannose & $1.2_{\mathrm{abcdehi}} \pm 0.06$ & $36.37_{\mathrm{a}} \pm 1.54$ & $1.00_{\mathrm{d}} \pm 0.25$ \\
saccharose & $1.47_{\mathrm{abceh}} \pm 0.07$ & $20.22_{\mathrm{cf}} \pm 4.04$ & $0.87_{\mathrm{d}} \pm 0.31$ \\
sorbitol & $1.03_{\mathrm{abcde}} \pm 0.17$ & $30.09_{\mathrm{ad}} \pm 0.22$ & $1.88_{\mathrm{ad}} \pm 1.41$ \\
starch & $0.98_{\mathrm{abcdehijkln}} \pm 0.24$ & $35.37_{\mathrm{a}} \pm 0.11$ & $12.71_{\mathrm{ac}} \pm 9.04$ \\
trehalose & $1.56_{\mathrm{abcehijk}} \pm 0.14$ & $74.15_{\mathrm{b}} \pm 1.70$ & $133.38_{\mathrm{b}} \pm 4.83$ \\
xylose & $0.05_{\mathrm{dflm}} \pm 0.01$ & $33.20_{\mathrm{ah}} \pm 2.73$ & $17.98_{\mathrm{ac}} \pm 4.71$ \\
\hline
\end{tabular}

Data presented as mean \pm SD $(n=3)$. The mean values given in lines with different letter indices are signif icantly different $(\alpha \leq 0.05)$. Composition of culture medium: arabinose/xylose/fructose/glucose/mannose/ cellobiose/galactose/lactose/maltose/sucrose/trehalose/soluble starch (40 g/L), $\mathrm{NH}_{4} \mathrm{NO}_{3}(4 \mathrm{~g} / \mathrm{L}), \mathrm{KH}_{2} \mathrm{PO}_{4}$ $(4.08 \mathrm{~g} / \mathrm{L}), \mathrm{Na}_{2} \mathrm{HPO}_{4} \times 2 \mathrm{H}_{2} \mathrm{O}(7.12 \mathrm{~g} / \mathrm{L}), \mathrm{MgSO}_{4} \times 7 \mathrm{H}_{2} \mathrm{O}(0.2 \mathrm{~g} / \mathrm{L}), \mathrm{CaCl}_{2}(0.0008 \mathrm{~g} / \mathrm{L}), \mathrm{FeSO}_{4} \times 7 \mathrm{H}_{2} \mathrm{O}$ $(0.0011 \mathrm{~g} / \mathrm{L})$, ethylenediaminetetraacetic acid $(0.0012 \mathrm{~g} / \mathrm{L})$.

The hydrolytic activity tests carried out on the agar medium with $1 \%$ soluble starch addition (Figure 1) clearly confirmed that the strain assimilated this substrate better than sodium carboxymethyl cellulose $(\mathrm{CMCNa})$ or tributyrin.

Glucose (monosaccharide) was the second-best source of carbon after starch. It also ensured the efficient production of surfactin analogues by B. subtilis natto BS19. The reduction in surface tension in the post-culture medium containing glucose, was approximately $45 \%$. However, the concentration of surfactin obtained with glucose was less than $10 \mathrm{mg} / \mathrm{L}$. The use of various carbon sources resulted in changes in the concentrations and relative amounts of individual isoforms synthesized by the studied strain (Figure 2). 

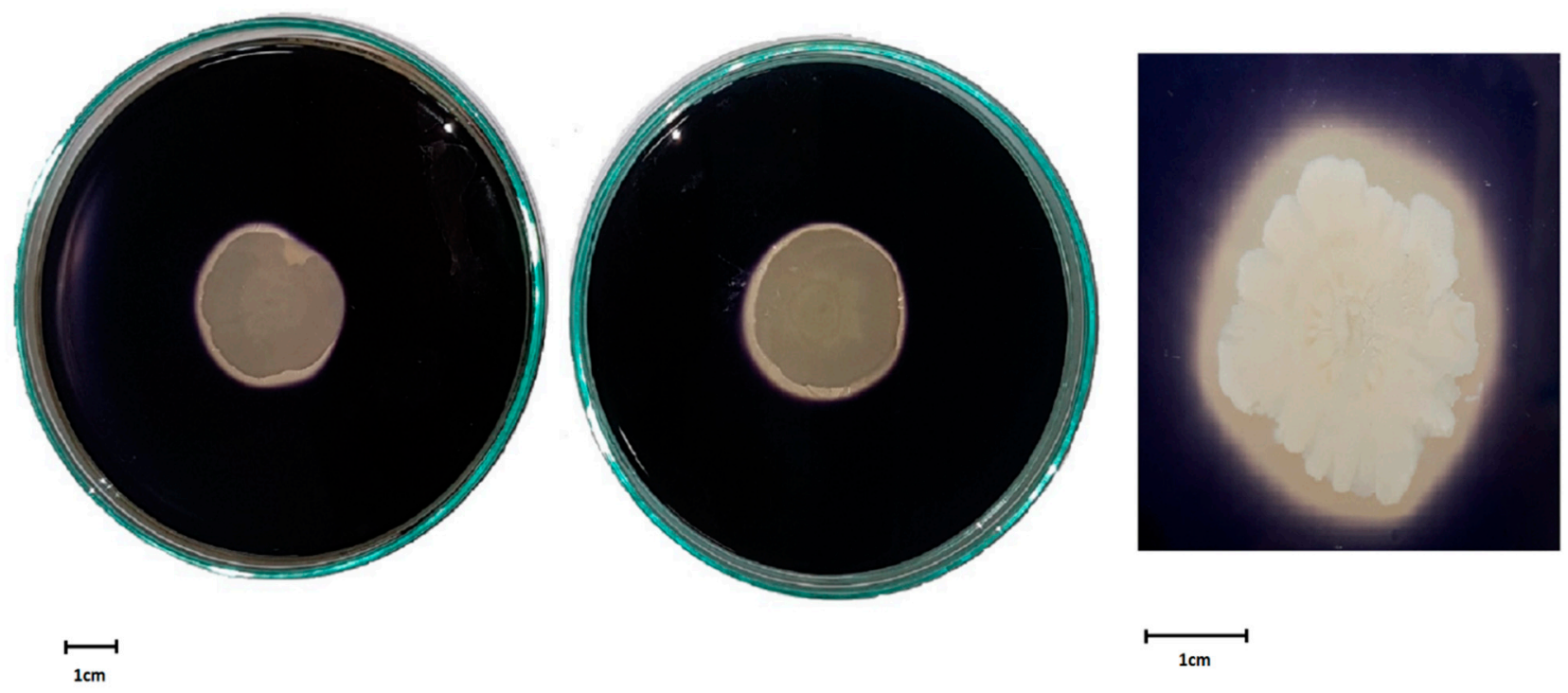

Figure 1. Clear zone around a single colony of B. subtilis natto BS19 on agar medium supplemented with $1 \%$ soluble starch after staining with Lugol's iodine.

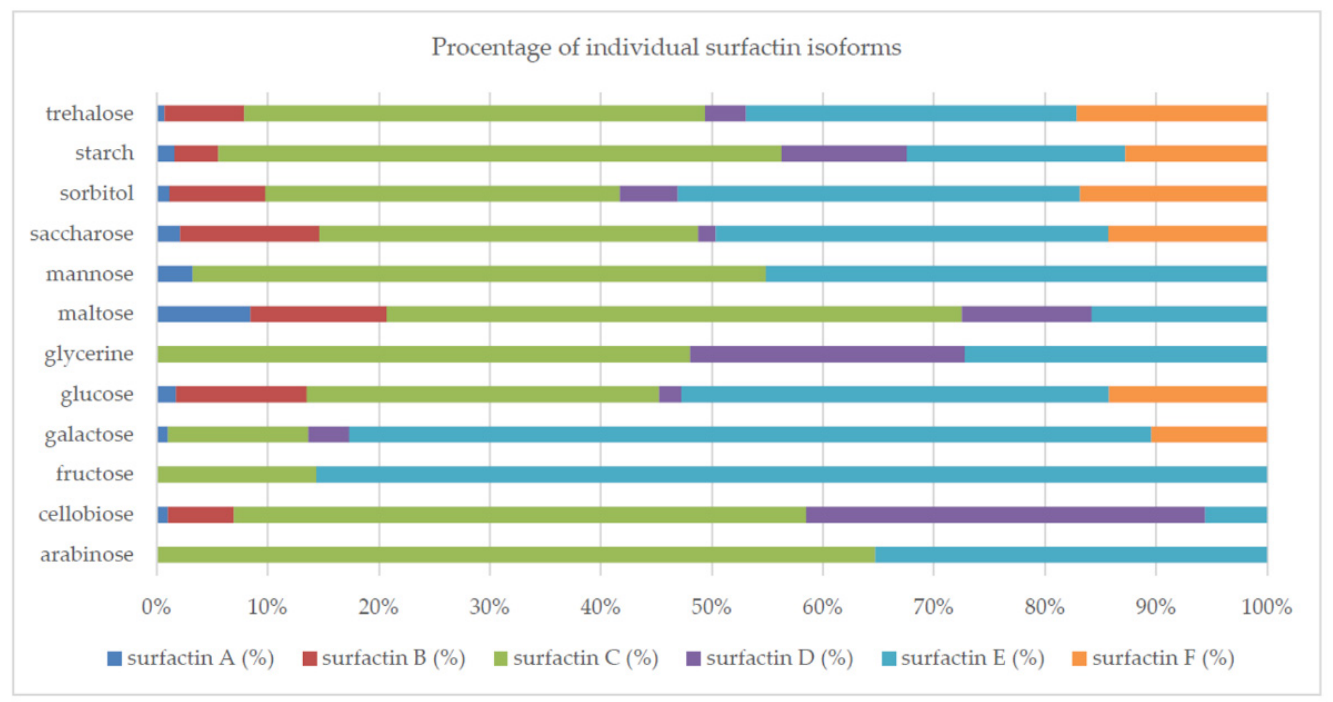

Figure 2. Percentage of individual surfactin isoforms for different carbon sources.

Two surfactin isoforms were synthesized with arabinose and fructose; three with glycerin, maltose and mannose; five with galactose and cellobiose; and six with the other sugars (glucose, sucrose, sorbitol, soluble starch and trehalose). Among the produced surfactin isoforms, the analogs marked as $\mathrm{C}$ and $\mathrm{E}$ dominated. The concentration $(\mathrm{mg} / \mathrm{L})$ of the isoforms produced by the tested strain differed significantly depending on the carbon source used in the culture medium (surfactin A: from 0.03 (mannose) to 2.14 (soluble starch); surfactin B: from 0.13 (maltose) to 5.26 (soluble starch); surfactin C: from 0.11 (fructose) to 67.64 (soluble starch); surfactin D from 0.06 (sucrose) to 15.05 (soluble starch); surfactin E from 0.10 (arabinose) to 26.23 (soluble starch); surfactin F from 0.52 (glucose) to 17.04 (soluble starch)).

\subsection{Synthetic Nitrogen Sources}

Four organic substrates (beef extract, malt extract, peptone, yeast extract) and a mineral one (ammonium nitrate) were tested as nitrogen sources in the microbial biosynthesis of surfactin. The culture medium $\mathrm{pH}$ was 7.0 and the incubation temperature was $37^{\circ} \mathrm{C}$. The beef extract contributed little to the production of surfactin (Figure 3a-c). 


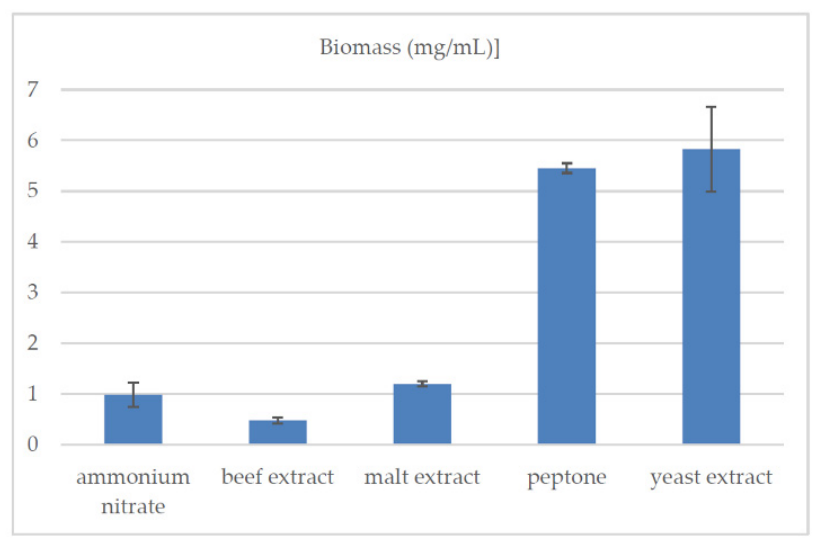

(a)

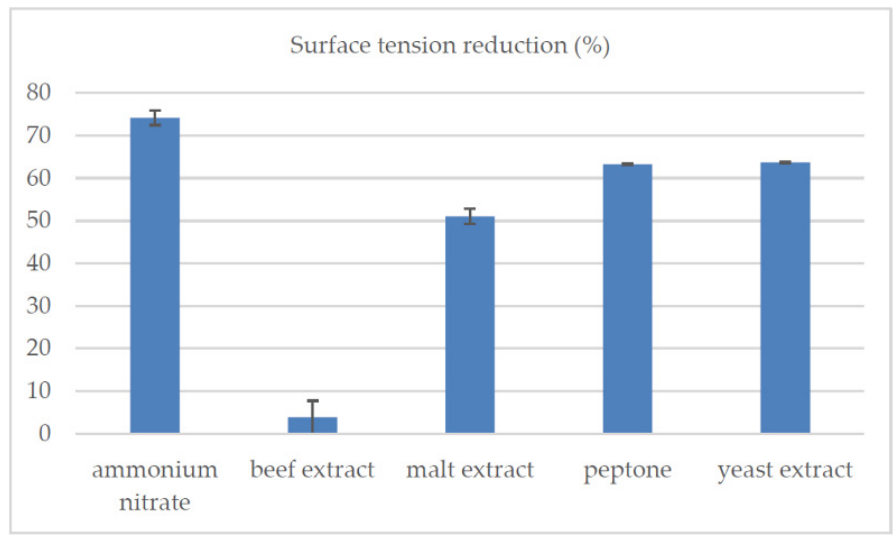

(b)

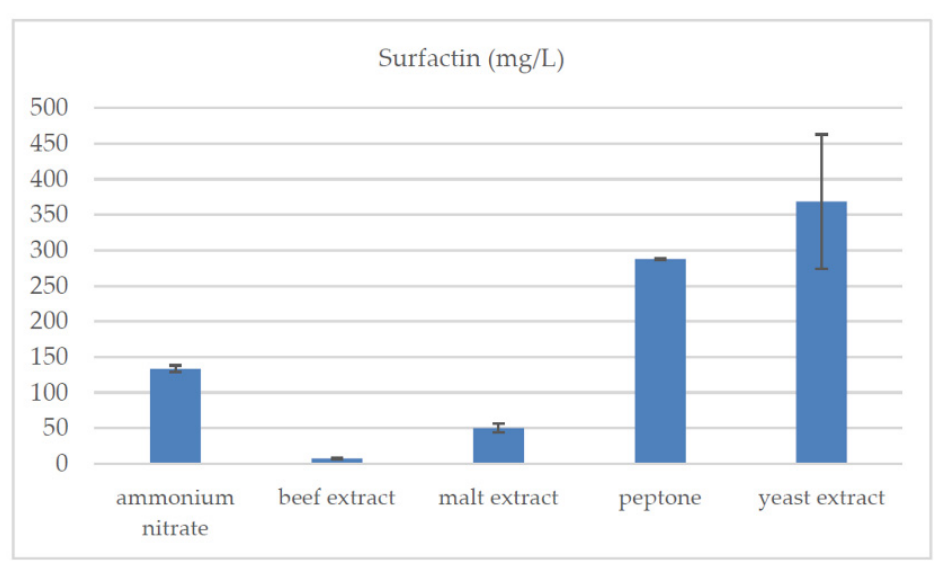

(c)

Figure 3. Influence of nitrogen source on (a) the concentration of B. subtilis natto BS19 biomass (mg/mL), (b) reduction of surface tension (\%) of the medium during the culture and (c) concentration of surfactin $(\mathrm{mg} / \mathrm{mL})$. Data presented as mean $\pm \mathrm{SD}$ for each nitrogen source $(n=3)$. The mean values given in lines with different letter indices are significantly different $(\alpha \leq 0.05)$. Composition of culture medium: soluble starch $(40 \mathrm{~g} / \mathrm{L}), \mathrm{NH}_{4} \mathrm{NO}_{3} /$ beef extract $/$ malt extract/peptone/yeast extract $(4 \mathrm{~g} / \mathrm{L}), \mathrm{KH}_{2} \mathrm{PO}_{4}(4.08 \mathrm{~g} / \mathrm{L}), \mathrm{Na}_{2} \mathrm{HPO}_{4} \times 2 \mathrm{H}_{2} \mathrm{O}(7.12 \mathrm{~g} / \mathrm{L}), \mathrm{MgSO}_{4} \times 7 \mathrm{H}_{2} \mathrm{O}(0.2 \mathrm{~g} / \mathrm{L}), \mathrm{CaCl} 2$ $(0.0008 \mathrm{~g} / \mathrm{L}), \mathrm{FeSO}_{4} \times 7 \mathrm{H}_{2} \mathrm{O}(0.0011 \mathrm{~g} / \mathrm{L})$, ethylenediaminetetraacetic acid $(0.0012 \mathrm{~g} / \mathrm{L})$.

Other sources, especially peptone and yeast extract, significantly promoted surfactin biosynthesis (peptone: $288.02 \pm 1.04 \mathrm{mg} / \mathrm{L}$, yeast extract: $368.36 \pm 94.23 \mathrm{mg} / \mathrm{L}$, as compared to ammonium nitrate: $133.38 \pm 4.83 \mathrm{mg} / \mathrm{L}$, malt extract: $50.10 \pm 6.18 \mathrm{mg} / \mathrm{L}$ and beef extract: $7.42 \pm 0.79 \mathrm{mg} / \mathrm{L})$. For all nitrogen sources, except for the beef extract, a significant reduction $(>50 \%)$ of the surface tension of the medium was observed. Supplementing the medium with peptone and yeast extract resulted in an average 4.5-times higher increase in bacterial biomass than with the use of ammonium nitrate or malt extract. On the other hand, when using the beef extract, the biomass concentration was more than 11 times lower than that in the medium with peptone or yeast extract. The use of yeast extract, malt extract or peptone promoted the biosynthesis of the E isoform. For ammonium nitrate and beef extract, the production of analogs $C$ and F, respectively, was observed. For all nitrogen sources, we obtained either 5 (for yeast extract, peptone, beef extract) or 6 surfactin isoforms (for malt extract, ammonium nitrate) (Figure 4). The concentration (mg/L) of surfactin analogs was determined by the availability of the nitrogen source in the culture medium (surfactin A: from 0.04 (beef extract) to 2.14 (ammonium nitrate), surfactin B: from 1.59 (beef extract) to 52.52 (yeast extract), surfactin C: from 0.37 (beef extract) to 99.86 (yeast extract), surfactin D: from 0.87 (malt extract) to 15.05 (ammonium nitrate), surfactin E: from 2.14 (beef extract) to 147.24 (yeast extract), surfactin F: from 3.27 (beef extract) to 63.10 (yeast extract)). 


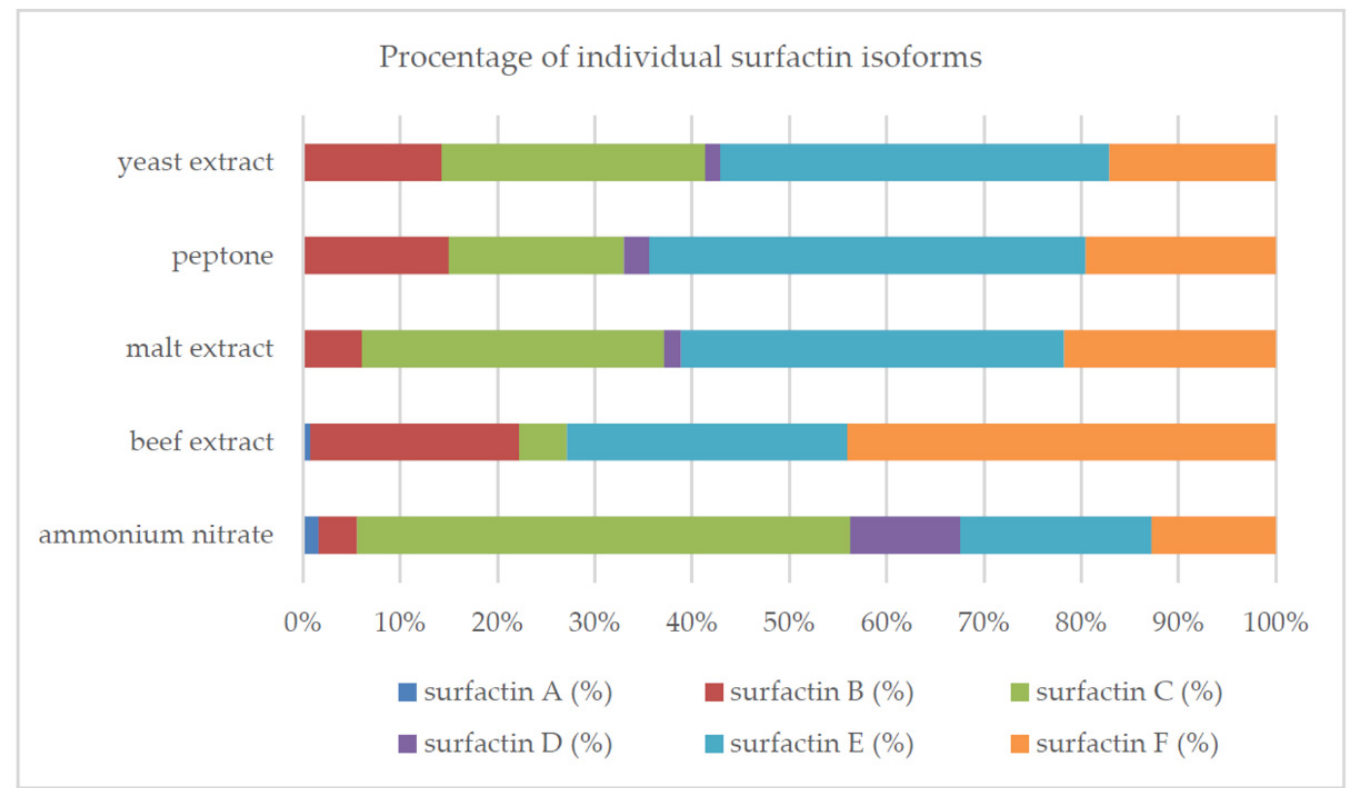

Figure 4. Percentage of individual surfactin isoforms for different nitrogen sources.

The almost complete lack of surfactant activity of the strain growing in the beef extract medium was probably due to the lack of the isoform $\mathrm{D}$ and the low total concentration of surfactin analogs. Interestingly, the lack of isoform A among the analogs produced by the same strain in media with yeast extract and peptone did not translate into the significant deterioration of surface-active properties (Figure 3b).

\subsection{Culture Conditions}

Both the $\mathrm{pH}$ and the temperature of the culture significantly influenced the biosynthesis of surfactin by B. subtilis natto BS19 (Figures $5 \mathrm{a}-\mathrm{c}$ and $6 \mathrm{a}-\mathrm{c}$ ).

The highest (statistically significant) concentration of this compound was achieved at $\mathrm{pH} 7.0$ and $37^{\circ} \mathrm{C}$. The increase in bacterial biomass was also the highest under these conditions. Strong reduction of surface tension $(>50 \%)$ at different $\mathrm{pH}(6.0,6.5,7.0,7.5$ and 8.0) and different temperatures $\left(30^{\circ} \mathrm{C}, 36^{\circ} \mathrm{C}, 37^{\circ} \mathrm{C}, 38^{\circ} \mathrm{C}\right.$ and $\left.40^{\circ} \mathrm{C}\right)$ indicated that in each case the concentration of produced surfactin was probably higher than the critical micelle concentration. It can therefore be concluded that, although the composition of the medium is a key determinant of surfactin biosynthesis by B. subtilis natto BS19, the production of this compound can be significantly increased by appropriate selection of the culture conditions. Interestingly, $\mathrm{pH}$ of the medium significantly influenced the biosynthesis of individual surfactin isoforms. At pH 7.0, Bacillus subtilis synthesized mixtures of six analogs with a high proportion of isoforms $\mathrm{C}$ and $\mathrm{E}$. The other $\mathrm{pH}$ values $(6.0,6.5,7.5,8.0)$ favored the production of analogs D and F (Figure 7). 


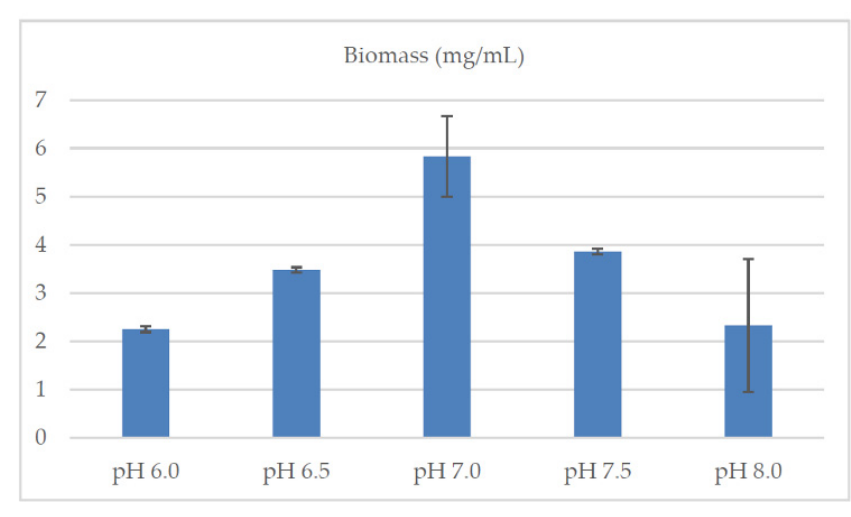

(a)

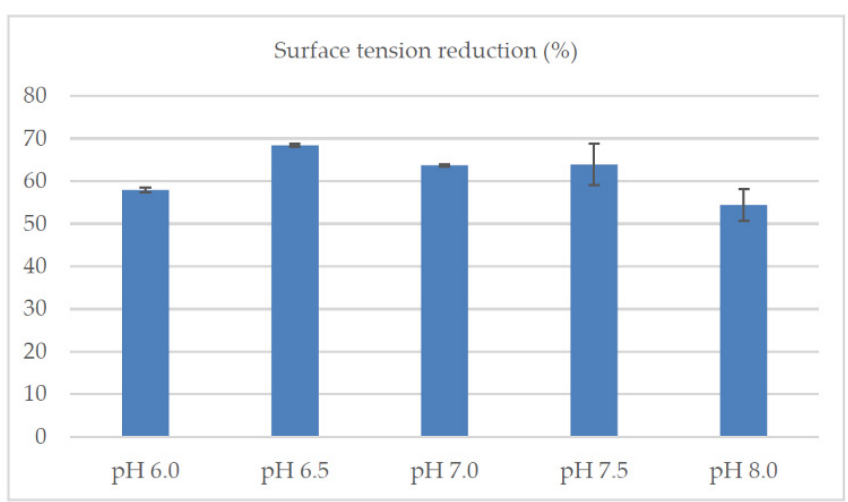

(b)

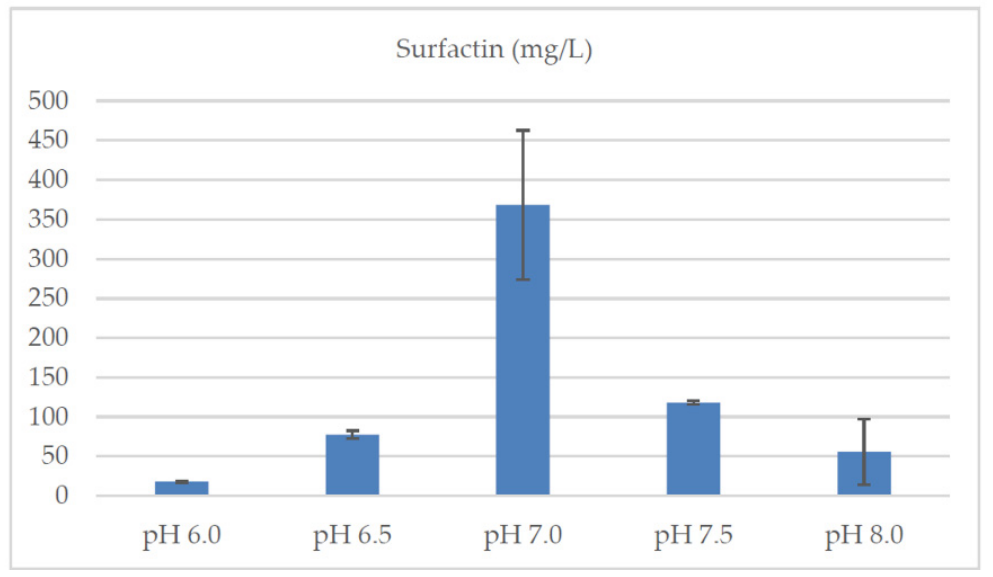

(c)

Figure 5. Influence of $\mathrm{pH}$ of the culture medium on (a) the concentration of B. subtilis natto BS19 biomass (mg/mL), (b) reduction of surface tension (\%) of the medium during the culture and (c) concentration of surfactin $(\mathrm{mg} / \mathrm{mL})$. Data presented as mean $\pm \mathrm{SD}(n=3)$. The mean values given in lines with different letter indices are significantly different $(\alpha \leq 0.05)$. Composition of culture medium: soluble starch $(40 \mathrm{~g} / \mathrm{L})$, yeast extract $(4 \mathrm{~g} / \mathrm{L}), \mathrm{KH}_{2} \mathrm{PO}_{4}(4.08 \mathrm{~g} / \mathrm{L}), \mathrm{Na}_{2} \mathrm{HPO}_{4} \times 2 \mathrm{H}_{2} \mathrm{O}$ $(7.12 \mathrm{~g} / \mathrm{L}), \mathrm{MgSO}_{4} \times 7 \mathrm{H}_{2} \mathrm{O}(0.2 \mathrm{~g} / \mathrm{L}), \mathrm{CaCl}_{2}(0.0008 \mathrm{~g} / \mathrm{L}), \mathrm{FeSO}_{4} \times 7 \mathrm{H}_{2} \mathrm{O}(0.0011 \mathrm{~g} / \mathrm{L})$, ethylenediaminetetraacetic acid $(0.0012 \mathrm{~g} / \mathrm{L})$.

In turn, the temperature of the culture did not have such a significant impact on the percentage of individual isoforms as $\mathrm{pH}$ did. At $36^{\circ} \mathrm{C}$ and $37^{\circ} \mathrm{C}, 4$ or 5 surfactin analogs, respectively, were produced. At other temperatures tested, the production of 6 isoforms was observed (Figure 8).

\subsection{Potato Peelings as an Alternative Carbon Source}

Potato peel extract (PP) can successfully replace synthetic soluble starch as a component of the culture medium in surfactin biosynthesis. An increase in the biosynthesis of the mixture of surfactin isoforms and in the cell biomass of B. subtilis natto BS19 was observed, depending on the percentage of potato extract in the culture medium. The concentration of surfactin produced with the use of PP was similar to that obtained for soluble starch as a carbon source at the incubation temperature of $30^{\circ} \mathrm{C}$ (Figure 6).

The surfactin concentration for PP was also higher than with the use of other analyzed carbon sources, except for the soluble starch in the variant with ammonium nitrate as the nitrogen source (Table 1, Figure 9). Additionally, the surface-active compounds formed as a result of microbiological synthesis lowered the surface tension of the PP medium by about 50\% (Figure 9). The percentage of the five isoforms (Figure 10) in the media with different amounts of potato extract was similar. 


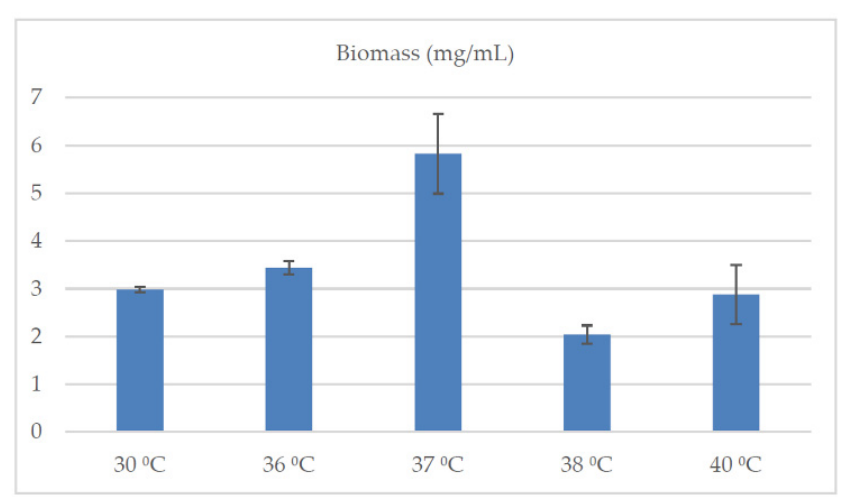

(a)

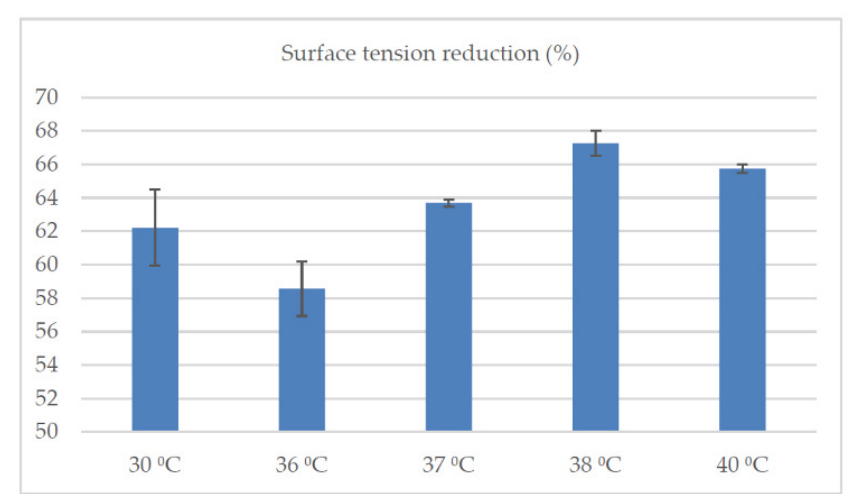

(b)

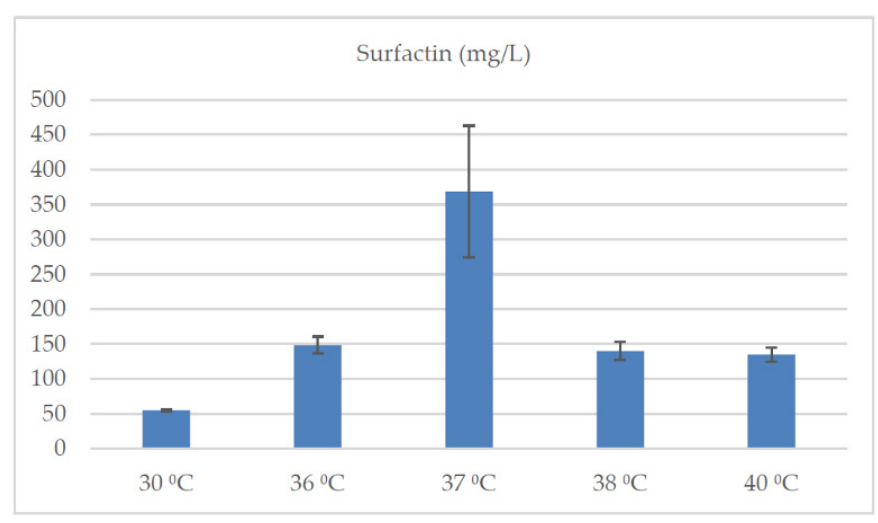

(c)

Figure 6. Influence of the temperature of the culture medium on (a) the concentration of B. subtilis natto BS19 biomass $(\mathrm{mg} / \mathrm{mL}),(\mathbf{b})$ reduction of surface tension (\%) of the medium during the culture and (c) concentration of surfactin $(\mathrm{mg} / \mathrm{mL})$. Data presented as mean $\pm \mathrm{SD}(n=3)$. The mean values given in lines with different letter indices are significantly different $(\alpha \leq 0.05)$. Composition of culture medium: soluble starch $(40 \mathrm{~g} / \mathrm{L})$, yeast extract $(4 \mathrm{~g} / \mathrm{L}), \mathrm{KH}_{2} \mathrm{PO}_{4}$ $(4.08 \mathrm{~g} / \mathrm{L}), \mathrm{Na}_{2} \mathrm{HPO}_{4} \times 2 \mathrm{H}_{2} \mathrm{O}(7.12 \mathrm{~g} / \mathrm{L}), \mathrm{MgSO}_{4} \times 7 \mathrm{H}_{2} \mathrm{O}(0.2 \mathrm{~g} / \mathrm{L}), \mathrm{CaCl}_{2}(0.0008 \mathrm{~g} / \mathrm{L}), \mathrm{FeSO}_{4} \times 7 \mathrm{H}_{2} \mathrm{O}(0.0011 \mathrm{~g} / \mathrm{L}), \mathrm{EDTA}$ $(0.0012 \mathrm{~g} / \mathrm{L})$.

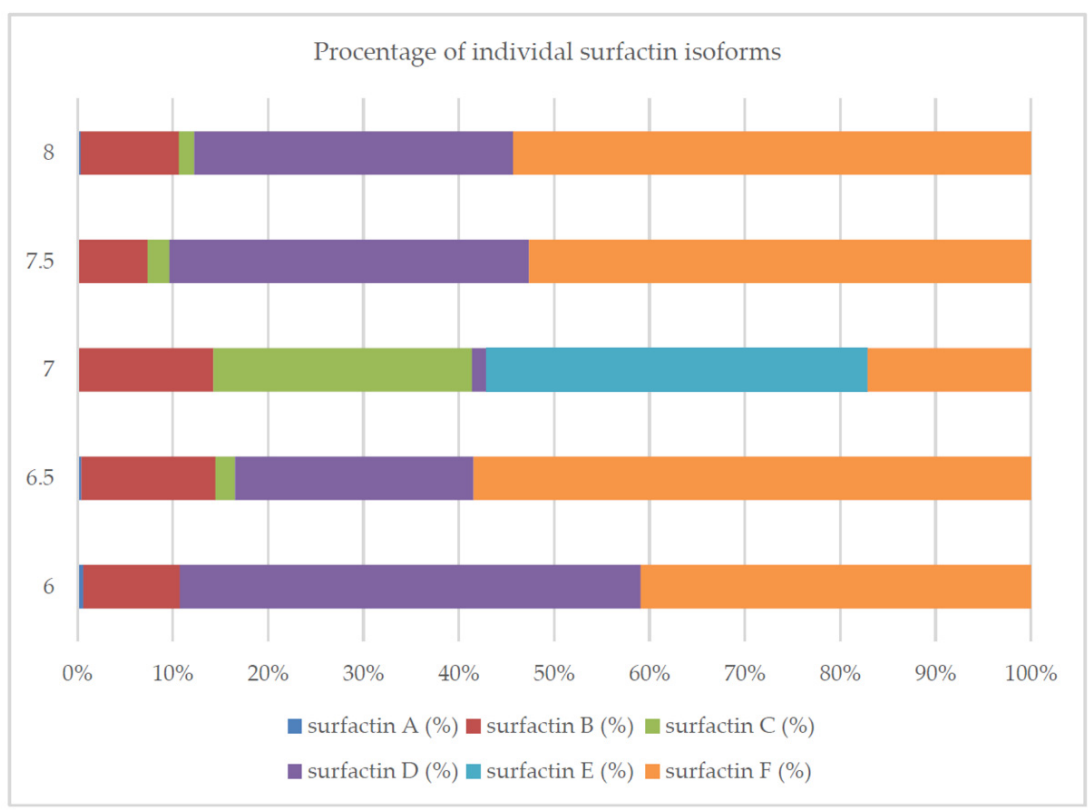

Figure 7. Percentage of individual surfactin isoforms for different $\mathrm{pH}$ of medium. 


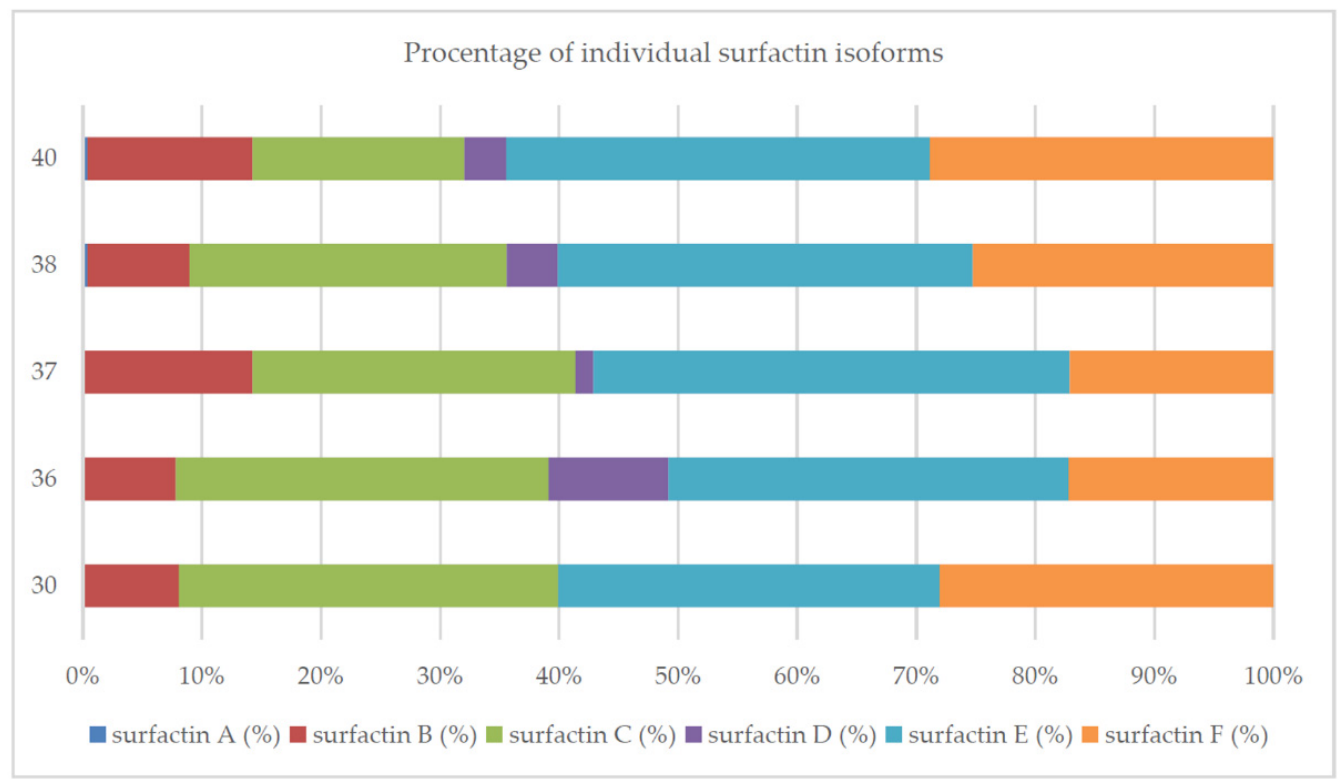

Figure 8. Percentage of individual surfactin isoforms for different temperatures of culture.

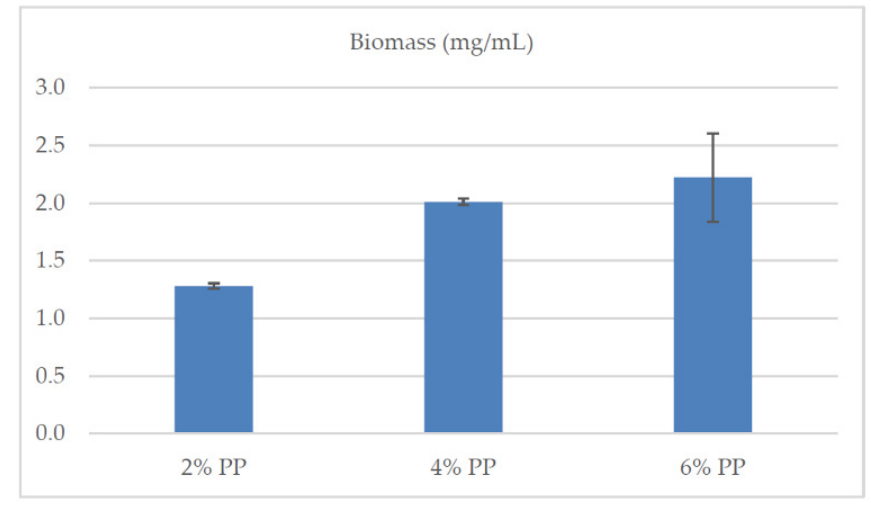

(a)

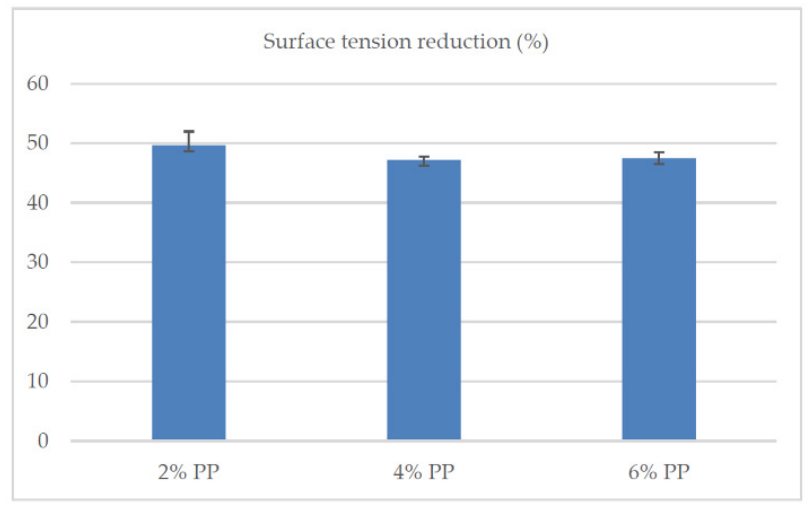

(b)

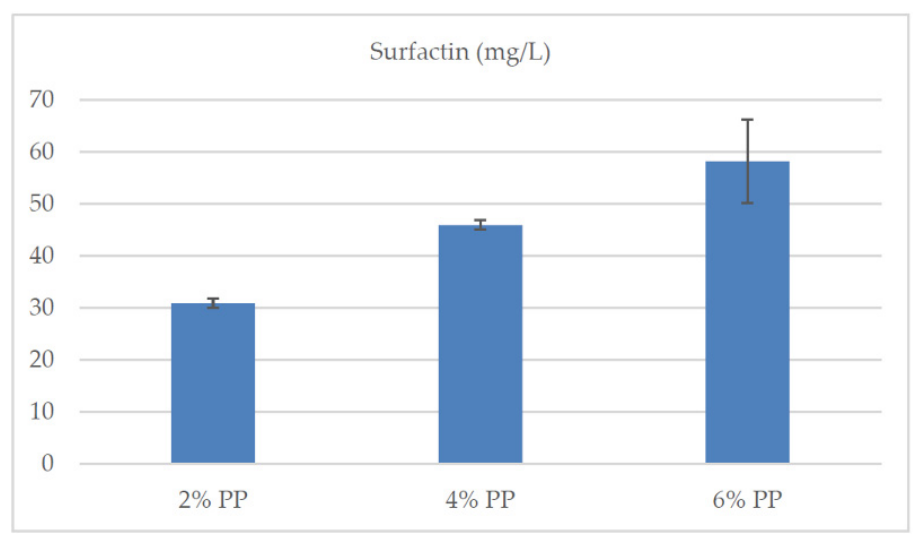

(c)

Figure 9. Influence of the alternative carbon source (potato peel extract) on (a) the concentration of B. subtilis natto BS19 biomass $(\mathrm{mg} / \mathrm{mL}),(\mathbf{b})$ reduction of surface tension $(\%)$ of the medium during the culture and (c) concentration of surfactin $(\mathrm{mg} / \mathrm{mL})$. Data presented as mean $\pm \mathrm{SD}(n=3)$. The mean values given in lines with different letter index are significantly different $(\alpha \leq 0.05)$. Composition of culture medium: potato peel extract $(\mathrm{PP})(2 \% / 4 \% / 6 \%)$, yeast extract $(4 \mathrm{~g} / \mathrm{L}), \mathrm{KH}_{2} \mathrm{PO}_{4}$ $(4.08 \mathrm{~g} / \mathrm{L}), \mathrm{Na}_{2} \mathrm{HPO}_{4} \times 2 \mathrm{H}_{2} \mathrm{O}(7.12 \mathrm{~g} / \mathrm{L}), \mathrm{MgSO}_{4} \times 7 \mathrm{H}_{2} \mathrm{O}(0.2 \mathrm{~g} / \mathrm{L}), \mathrm{CaCl}_{2}(0.0008 \mathrm{~g} / \mathrm{L}), \mathrm{FeSO}_{4} \times 7 \mathrm{H}_{2} \mathrm{O}(0.0011 \mathrm{~g} / \mathrm{L})$, ethylenediaminetetraacetic acid $(0.0012 \mathrm{~g} / \mathrm{L})$. 


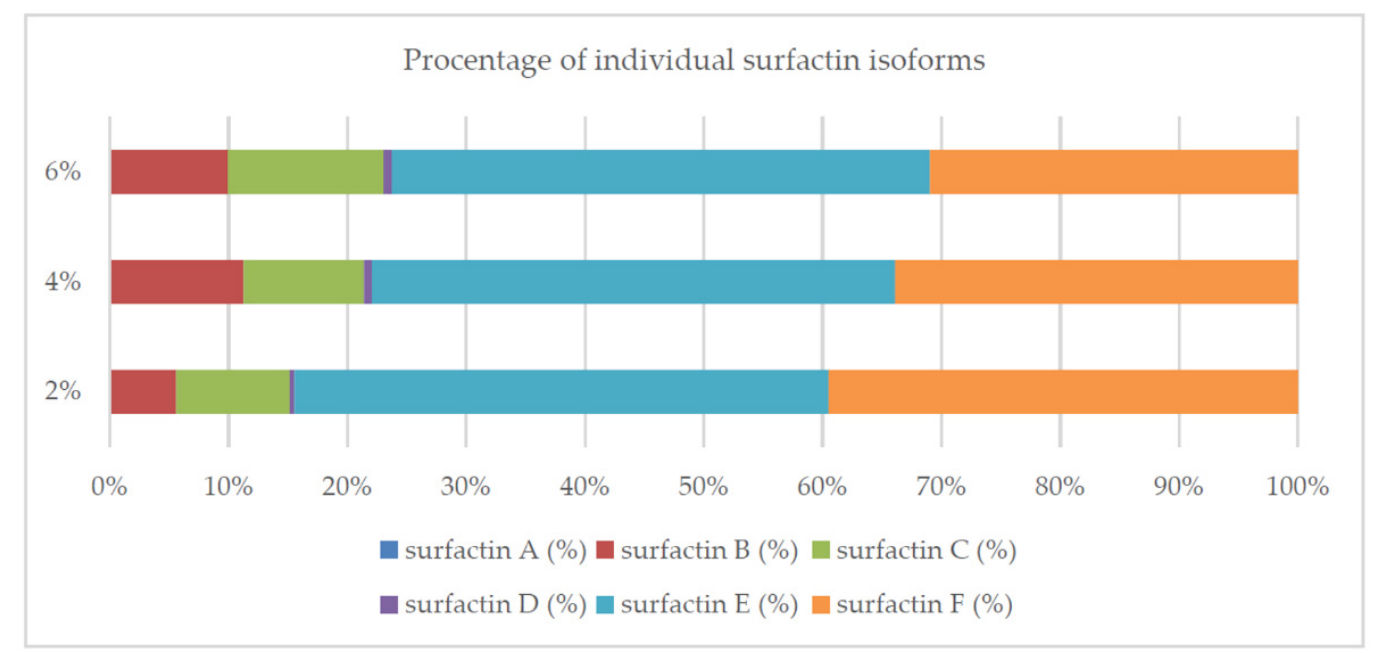

Figure 10. Percentage of individual surfactin isoforms for different amounts of potato extract added to the culture medium.

Slight deviations were found in the medium containing $2 \%$ PP: the concentration of isoform $\mathrm{B}$ was lower and the concentration of isoform $\mathrm{F}$ higher than in the other variants. In the PP medium, the tested strain produced more isoform $\mathrm{F}$ and less isoform $\mathrm{C}$ compared to the medium containing synthetic starch. These differences are reflected in the surfactant activity of the synthesized mixture (ST reduction was $>60 \%$ in starch medium as compared to $>45 \%$ in PP medium (Figures 6 and 9).

\section{Discussion}

The biosynthesis and properties of surfactants are determined by the genetic characteristics of the microorganism strain, the composition of the medium, and the growth conditions [28,37]. Therefore, the selection of nitrogen and carbon sources as well as the culture parameters influence the production of surfactin isoforms by the Bacillus subtilis natto BS19 strain. On the other hand, analysis of the trophic profile and metabolic activity of a given strain, enables the search for waste substrates that are a cheaper alternative to synthetic media.

In this study soluble starch, among the synthetic carbon sources we tested, turned out to be a carbohydrate not only conducive to the growth of B. subtilis natto BS19 (Figure 1), but also ensuring the highest efficiency of surfactin biosynthesis (Table 1). Other authors also demonstrated that this compound could be used as a substrate in the biosynthesis of surfactin and other lipopeptide biosurfactants $[18,38-40]$. Bacillus bacteria were shown to produce $\alpha$-amylase, which randomly catalyzed the hydrolysis of $\alpha-1,4$ glycosidic bonds inside the potato starch chain [41,42]. Hence, starch is a very good substrate for these bacteria. However, most researchers consider glucose and sucrose either as the optimal carbon source for the studied microorganisms $[18,27]$, or as components that largely determine the effectiveness of surfactin biosynthesis [21]. Singh et al. [25] reported the maximum efficiency of biosurfactant production by the Bacillus amyloliquefaciens AR2 strain using sucrose as a carbon source (surface tension reduction $30-37 \mathrm{mM} / \mathrm{m}$; critical micelle concentration (CMC) $80-110 \mathrm{mg} / \mathrm{L}$; emulsification index (EI) (kerosene) 32-66\%). The above data indicate that each strain exhibits its own ability to absorb individual carbohydrates. Interestingly, the B. subtilis natto BS19 strain produced more surfactin when grown on starch medium than in the presence of sucrose or glucose (Table 1) which is worth further analysis.

The presence of certain additional compounds in the media, such as growth stimulants (vitamins, amino acids) could be crucial for the development of a given strain [43]. The preferences for nitrogen source result from the need to assimilate a specific vitamin or amino acid, which may also translate into surfactin biosynthesis by B. subtilis natto BS19. Casein peptone, yeast extract, malt extract and beef extract differ in the qualitative and 
quantitative composition of amino acids, vitamins and carbohydrates. Casein peptone is an especially rich source of amino acids (tryptophan) and proteins [44]. Yeast extract contains carbohydrates, amino acids (especially glutamic acid), B vitamins (including biotin) and nucleotides [45]. Malt extract is also a rich source of carbohydrates (maltose, fructose, glucose and dextrins) and meat extract contains many B vitamins $[46,47]$. Both peptone and yeast extract turned out to be a better nitrogen source for B. subtilis BS19 than beef extract, malt extract or inorganic ammonium nitrate (Figure $3 \mathrm{a}-\mathrm{c}$ ). Similar results were reported by Cheng et al. [19], who supplemented B. subtilis cultures with yeast. They observed a $2 \%$ increase in bacterial biomass and found that the supplementation used was more effective in the production of biosurfactants than the use of fish or soy extract. Paraszkiewicz et al. [12] also used a medium supplemented with an extract of waste products (two different brewery wastewaters, beet molasses, apple peel extract), containing peptone and yeast extract. In turn, Abushady et al. [18] reported that inorganic nitrogen sources, such as ammonium nitrate and sodium nitrate, guaranteed a higher microbial production of surfactin $(2.2 \mathrm{~g} / \mathrm{L}$ and $1.9 \mathrm{~g} / \mathrm{L}$, respectively) than media containing yeast of peptone.

The culture medium $\mathrm{pH}$ and the temperature also influenced the synthesis of surfactin by B. subtilis natto BS19. The highest level of surfactin synthesis by the studied strain was observed at $\mathrm{pH} 7.0$ and $37.0^{\circ} \mathrm{C}$ (Figures $5 \mathrm{c}$ and $6 \mathrm{c}$ ). Chen et al. [20] showed that maintaining a constant $\mathrm{pH}$ enabled the biosynthesis of significant amounts of biosurfactants, including surfactin. Sen and Swaminathan [48] analyzed the effect of $\mathrm{pH}$ and temperature on the synthesis of surfactin by B. subtilis DSM 3256. The maximum production of surfactin $(1.1 \mathrm{~g} / \mathrm{L})$ by the strain was obtained at $37.4{ }^{\circ} \mathrm{C}$ and $\mathrm{pH}$ 6.75. Abushady et al. [18] changed the $\mathrm{pH}$ of the medium from 5.0 to 9.0 in 0.5 steps. The highest concentration of surfactin (2.8 g/L) was found at $\mathrm{pH} 6.5$, followed by 7 (2.4 g/L). A similar $\mathrm{pH}$ range (6.0-9.0) was analyzed by Abdel-Mawgoud et al. [28] in their study on the production of biosurfactants by Bacillus subtilis BS5. The highest increase in biomass they reached at $\mathrm{pH} 6.5-9.0$, and the highest production of surfactin $(2.25 \mathrm{~g} / \mathrm{L})$ at $\mathrm{pH} 6.8$. In summary, the highest surfactin production is observed at $\mathrm{pH}$ of around 7.0 and $37^{\circ} \mathrm{C}$.

Surfactins are produced as a mixture of many analogs with a different structure, which translates into the biological and surface-active properties of this compound [10,40,49]. In this study, we confirmed that the composition of the medium and the culture conditions (especially $\mathrm{pH}$ ) determined the number of isoforms produced and their percentage in the surfactin concentration (Figures 2, 4, 7, 8 and 10). However, there is still little work available on the biosynthesis of different surfactin variants in response to the modification of medium composition and culture conditions. Liu et al. [40] showed that the addition of various amino acids to the medium significantly affected the proportion of surfactin isoforms produced. When Arg, Gln or Val was added to the medium, more analogs with even $\beta$-hydroxy fatty acids were produced. In contrast, the addition of Cys, His, Ile, Leu, Met, Ser or Thr increased the proportion of surfactin variants with odd $\beta$-hydroxy fatty acids. Bartal et al. [37] presented a detailed study on the influence of the carbon source and $\mathrm{Mn}^{2+}, \mathrm{Cu}^{2+}$ and $\mathrm{Ni}^{2+}$ ions on the production of various surfactin analogs. They found that xylose and fructose had the greatest influence on the ratios of different analogs. Furthermore, Jajor et al. [10] showed that the culture conditions (aeration) of B. subtilis strains (KB1 and \#309) influenced the proportions of the isoforms produced. A lower amount of oxygen decreased the proportion of the C15 isoforms in favor of the C12 analogs. Thus, biosynthesis of the desired surfactin analog depends on both the properties of the strain and the culture conditions.

In this study we tested the feasibility of using the selected waste product as a cheaper alternative to soluble starch. Commercialization of the production of surfactin analogs is currently difficult due to the high costs of their production. There are many cheaper alternatives to these products, such as sodium lauryl sulfate (SDS) which is a hundred times cheaper than the surfactin offered by Sigma Chemical Company. For this reason, efforts are made to reduce the cost of surfactin production. For example, attempts were 
made to reduce the expenditure on media components, which account for up to $50 \%$ of the total production costs of the compound [2,50]. We chose potato peelings because they are a waste product widely available in many countries. Importantly, potatoes are grown mainly in Europe and Asia [51]. Depending on the purpose of the treatment, they are usually peeled by the steam or abrasion methods. As a result, a large amount of peelings is created, the disposal of which is a serious problem for the industry. Annually, up to 140,000 tons of potato peelings are produced worldwide, most of which ends up in landfills [52]. Therefore, the use of this waste material not only reduces the cost of surfactin production, but also solves the problem of its management, which is desirable for environmental protection [53].

On the other hand, potato skins contain a wealth of various substances, including carbohydrates (mainly starch), vitamins and important elements [54]. We showed that the potato peel extract used promoted surfactin biosynthesis by B. subtilis BS 19. Additionally, the increase in the percentage of the extract in the medium translated into an increase in the production of surfactin (Figure 9c). Other studies demonstrated that most microorganisms of the genus Bacillus are hydrolytic to complex organic compounds [55]. Researches confirmed that starch-rich waste can be used as a substrate for the production of biosurfactants [32,56-59]. Ansari et al. [59] also analyzed the supplementation of the medium with nitrogen (sodium nitrate, urea). They reported that nitrogen supplementation stimulated the growth of microorganisms but had no effect on biosurfactant biosynthesis. The use of potato skins as an economic carbon source in the production of biosurfactants was also shown by Sharma et al. [53]. Bacillus pumilus DSVP18 strain used potato peelings as the only carbon source for the biosynthesis of biosurfactant $(3.2 \pm 0.32 \mathrm{~g} / \mathrm{L})$, which retained its surface-active properties in a wide range of temperature $\left(20-120^{\circ} \mathrm{C}\right), \mathrm{pH}(2-12)$ and salinity $(2-12 \%)$. Moreover, the microbial production of this biosurfactant resulted in a reduction of the surface tension of the medium from 72 to $28.7 \mathrm{nM} / \mathrm{m}$. Waste potato peelings were also used in the microbial production of biosurfactants by Pande et al. [55]. Using this waste material, the B. subtilis DDU20161 strain synthesized $253.79 \mathrm{mg} / \mathrm{L}$ of surfactant after $40 \mathrm{~h}$ of culture.

In further studies with B. subtilis natto BS19, it is necessary to establish the structure as well as the surface-active and biological properties of the produced isoforms. In the next stage of the research, we intend to determine the composition of the medium and the growing conditions that enable the production of a surfactin isoform with the desired properties.

\section{Materials and Methods}

\subsection{Microorganism}

The native strain of Bacillus subtilis natto BS19, showing surfactin-producing ability, was isolated from a food product named natto by a multi-stage screening process as described by Koim-Puchowska et al. [60]. Bacterial isolates were identified by sequence analysis of the 16S rRNA gene. The research material was deposited into a cryobank (Grasso Biotech, Starogard Gdańsk, Poland) and stored at $-20{ }^{\circ} \mathrm{C}$ until the analysis. Before the experiments, pure cultures of B. subtilis natto BS19 were transferred from the cryobank, plated on an agar plate, and then grown on agar slants $\left(\mathrm{T}=37^{\circ} \mathrm{C} ; \mathrm{t}=72 \mathrm{~h}\right)$. The cultures on agar slants were stored at $+4{ }^{\circ} \mathrm{C}$.

\subsection{The Media and Culture Conditions}

Before the mineral medium was inoculated, the B. subtilis natto BS19 strain was grown in nutrient broth (5 g/L tryptone peptone, $2.5 \mathrm{~g} / \mathrm{L}$ yeast extract, $1 \mathrm{~g} / \mathrm{L}$ glucose, $\mathrm{pH}$ 7.2-7.4) for $24 \mathrm{~h}$ at rpm = 70. Mineral medium [13], containing $40 \mathrm{~g} / \mathrm{L}$ glucose, $4 \mathrm{~g} / \mathrm{L} \mathrm{NH}_{4} \mathrm{NO}_{3}$, $4.08 \mathrm{~g} / \mathrm{L} \mathrm{KH}_{2} \mathrm{PO}_{4}, 7.12 \mathrm{~g} / \mathrm{L} \mathrm{Na}_{2} \mathrm{HPO}_{4} \times 2 \mathrm{H}_{2} \mathrm{O}, 0.2 \mathrm{~g} / \mathrm{L} \mathrm{MgSO}_{4} \times 7 \mathrm{H}_{2} \mathrm{O}, 0.0008 \mathrm{~g} / \mathrm{L} \mathrm{CaCl}_{2}$, $0.0011 \mathrm{~g} / \mathrm{L} \mathrm{FeSO}_{4} \times 7 \mathrm{H}_{2} \mathrm{O}, 0.0012 \mathrm{~g} / \mathrm{L}$ ethylenediaminetetraacetic acid (EDTA) and $\mathrm{pH}$ 7.0 , was inoculated with $2.5 \mathrm{mg}$ of bacteria. The mineral medium was modified using various synthetic sources of carbon and nitrogen, which resulted in numerous variants of the medium. In the first stage of the research, 14 carbon sources, differing in structure 
and chemical properties, were examined in order to learn about the trophic profile of the strain under study and the usefulness of individual compounds in the microbiological synthesis of surfactin. As synthetic carbon sources we used monosaccharides (arabinose, xylose, fructose, glucose, mannose), disaccharides (cellobiose, galactose, lactose, maltose, sucrose, trehalose) and soluble starch (a polysaccharide). Two sugar alcohols were also tested: glycerin and sorbitol. In the first stage of the research, inorganic ammonium nitrate was used as the nitrogen source in accordance with the original composition of the culture medium [13]. Hence, in the second stage of the study, four organic nitrogen sources were used as an alternative to ammonium nitrate: yeast extract, beef extract, malt extract and casein peptone. All these nitrogen sources have been used so far in surfactin biosynthesis [21]. Having selected the optimal carbon and nitrogen source for B. subtilis natto BS19, in the next two stages of the research, we focused on determining the effect of culture conditions (culture $\mathrm{pH}$ and temperature) on surfactin biosynthesis. Cultures with shaking $(70 \mathrm{rpm})$ were carried out in triplicate in flasks $(\mathrm{v}=250 \mathrm{~mL})$ for $120 \mathrm{~h}$ at four different $\mathrm{pH}$ values, 6.0, 6.5, 7.5 and 8.0, in addition to the previously tested variant at $\mathrm{pH} 7.0$ and $37^{\circ} \mathrm{C}$. After verification of this parameter, the cultures were additionally carried out at four other temperatures: $30^{\circ} \mathrm{C}, 36^{\circ} \mathrm{C}, 38^{\circ} \mathrm{C}$ and $40^{\circ} \mathrm{C}$. In the last stage of the study, the use of an aqueous extract of potato peelings (PP) as an alternative to a synthetic carbon source in surfactin biosynthesis was assessed. To this end, the potato peelings were rinsed three times with distilled water and dried at $55^{\circ} \mathrm{C}$ for $96 \mathrm{~h}$, and then ground in an analytical mill. To obtain the potato extract, an aqueous suspension $10 \%(w / v)$ of the dried material was autoclaved $\left(\mathrm{T}=121{ }^{\circ} \mathrm{C}, \mathrm{t}=15 \mathrm{~min}\right)$, filtered through gauze and then through paper filter under reduced pressure. Potato peel water extract was added to the culture media $(2 \%, 4 \%$ or $6 \%)$ instead of the synthetic carbon source [32,61].

\subsection{Determination of Bacillus Subtilis Natto BS19 Biomass Concentration}

In order to measure the optical density of the cell suspension of B. subtilis natto BS19, $5 \mathrm{~mL}$ of the material were taken from each flask (in duplicate) and then centrifuged (MPW260R laboratory centrifuge, MPW-Med. Instruments, Warszawa, Poland). After decanting the supernatant, the material was suspended in sterile $0.9 \% \mathrm{NaCl}$, vortexed $(\mathrm{t}=30 \mathrm{~s})$ and centrifuged again; this was repeated twice to completely remove the culture medium from the sample. The optical density (OD600) of the cell suspension in sterile $0.9 \% \mathrm{NaCl}$ was measured using a UV-vis spectrophotometer (Pharo 300, Merck). The cell biomass concentration $(\mathrm{mg} / \mathrm{mL})$ in inoculum and post-culture medium was determined using a curve showing the relationship between cell biomass dry weight and optical density (OD). The curve was prepared with a pure line culture of Bacillus subtilis no. ŁO820 from the Collection of Industrial Strains, Łódź University of Technology, Łódź, Poland. The biomass was dried to a constant mass using a weighting dryer (RADWAG WPS-30S, Radwag, Radom, Poland) at $105^{\circ} \mathrm{C}$ and 20 s sampling time [60].

\subsection{Reduction of the Surface Tension of the Culture Medium}

The reduction of the surface tension of the medium during the culture was determined as the difference in the surface tension measured before inoculation and after the culture was completed. The surface tension was measured in triplicate by the du Noüy ring method using a tensiometer (PI-MT1M model, Donserv, Warszawa, Poland). Measurements performed after the culture was completed were preceded by the removal of the cell biomass from the culture medium by centrifugation $\left(2400 \times g, t=15 \mathrm{~min}, \mathrm{~T}=4{ }^{\circ} \mathrm{C}\right.$ [62].

\subsection{Surfactin Extraction and Determination of Its Concentration}

Affinity chromatography with a SPE (solid-phase extraction) system was used to extract surfactin isoforms. In the process we used Agilent Technologies Bond Elut C18 columns (Santa Clara, CA, USA), dedicated to the isolation of hydrophobic compounds. A detailed procedure of surfactin extraction was previously described in Koim-Puchowska et al. [60]. The surfactin concentration was determined by high performance liquid chromatography 
(HPLC) using an Agilent Technologies model 1220 device equipped with a diode detector. The chromatographic separation was carried out under the following conditions: Poroshell 120 EC-C18 column $(4.6 \times 150 \mathrm{~mm})$, mobile phase 80:20 (acetonitrile: $3.8 \mathrm{mM}$ trifluoroacetic acid), $40^{\circ} \mathrm{C}$, detection at $205 \mathrm{~nm}$. The concentration of surfactin was calculated as the sum of the peaks of all 6 isoforms using the external standard (ESTD) method. The concentration of surfactin isoforms was determined by HPLC using surfactin provided by Sigma Aldrich (St. Louis, MO, USA) (Surfactin from Bacillus subtilis, $\geq 98.0 \%-$ S3523).

\subsection{Measurement of the Hydrolytic Activity of Microorganisms}

Tests evaluating the hydrolytic activity of $B$. subtilis natto BS19 against various types of substrates were carried out on agar media (tryptone peptone $5 \mathrm{~g} / \mathrm{L}$, yeast extract $2.5 \mathrm{~g} / \mathrm{L}$, glucose $1 \mathrm{~g} / \mathrm{L}, 15 \mathrm{~g} / \mathrm{L}$ agar, $\mathrm{pH}$ 7.2-7.4, containing 1\% soluble starch, $1 \%$ cooking oil, or $1 \%$ skim milk), and on Vogels agar with $1 \%$ low viscosity sodium carboxymethylcellulose (CM$\mathrm{CNa})\left(1 \% \mathrm{CMCNa}, 5 \mathrm{~g} / \mathrm{L} \mathrm{Na}_{3} \mathrm{C}_{6} \mathrm{H}_{5} \mathrm{O}_{7}, 5 \mathrm{~g} / \mathrm{L} \mathrm{KH}_{2} \mathrm{PO}_{4}, 2 \mathrm{~g} / \mathrm{L} \mathrm{NH}_{4} \mathrm{NO}_{3}, 4 \mathrm{~g} / \mathrm{L}\left(\mathrm{NH}_{4}\right)_{2} \mathrm{SO}_{4}\right.$, $0.2 \mathrm{~g} / \mathrm{L} \mathrm{MgSO}_{4}, 1 \mathrm{~g} / \mathrm{L}$ peptone, $2 \mathrm{~g} / \mathrm{L}$ yeast extract, $15 \mathrm{~g} / \mathrm{L}$ agar, $\mathrm{pH}$ 5.5). Solid media were inoculated with B. subtilis natto BS19 using a sterile loop. Agar plates were incubated for $48 \mathrm{~h}$ at $30^{\circ} \mathrm{C}$. The surfaces of the agar plates containing $1 \%$ soluble starch were then flooded with Lugol's iodine for 1-2 min. The surfaces of the agar plate supplemented with $1 \% \mathrm{CMCNa}$ were flooded with $0.1 \%$ aqueous solution of Congo red for $30 \mathrm{~min}$; after decanting the reagent, the surface of the plate was flooded with $1 \mathrm{M} \mathrm{NaCl}$ aqueous solution for $10 \mathrm{~min}$. After performing the above-mentioned tests, all substrates were examined for the presence of clear hemolysis zones $[10,63]$.

\subsection{Statistical Analysis}

The experiments were performed in triplicate $(n=3)$. Results are presented as mean \pm standard deviation (SD). The analysis of variance (ANOVA) and Tukey's test for equal groups were used to verify the influence of the substrate composition and culture conditions on: (i) B. subtilis natto BS19 biomass concentration, (ii) reduction of the surface tension of the medium during the culture and (iii) the final concentration of the synthesized surfactin isoforms. Statistica v. 13.3 (TIBCO Software Inc. Palo Alto, CA, USA) and Excel software were used to analyze the obtained data.

\section{Conclusions}

The presented results confirm that the medium composition largely determines the growth of B. subtilis natto BS19 cell biomass and the biosynthesis of surfactin, which translates into differences in the reduction of the surface tension of the medium. The highest efficiency of surfactin production was found with the use of soluble starch as a carbon source (368.36 $\pm 94.23 \mathrm{mg} / \mathrm{L})$, although most authors point to glucose or sucrose. On the other hand, supplementation of the medium with an organic nitrogen source (yeast extract, peptone) instead of ammonium nitrate used in Cooper's medium resulted in about 5 times higher concentration of cell biomass; surfactin biosynthesis in media with peptone and yeast extract increased two- and three-fold, respectively. Factors such as temperature and $\mathrm{pH}$ of the culture also influenced the cell biomass, surface tension and surfactin concentration. The best results in the production of this compound were observed at $\mathrm{pH} 7.0$ and $37^{\circ} \mathrm{C}$. Potato peel extract proved to be a cheaper alternative to soluble starch. A significant influence of this substrate on the production of surfactin was confirmed by the increase in the average cell biomass of B. subtilis natto BS19; it was also observed that the higher the percentage of extract in the medium, the higher the surfactin biosynthesis (mean biomass concentration $(\mathrm{mg} / \mathrm{mL}) /$ mean surfactin concentration $(\mathrm{mg} / \mathrm{L})$ : $2 \% / 1.28 / 30.93 / ; 4 \% / 2.01 / 45.96 / ; 6 \% / 2.22 / 58.2 /$. Regardless of the amount of potato peel extract in the medium $(2 \%, 4 \%, 6 \%)$, a reduction in the surface tension of the medium was observed (up to $50 \%$ ). This suggests that in all experimental variants this compound was produced at the CMC level. Bacillus subtilis natto BS19 is a strain capable of biosynthesis of various surfactin isoforms. The percentage of each isoform is largely determined by 
the composition of the medium and especially $\mathrm{pH}$ of the culture. Further studies are necessary to investigate the structure of individual isoforms that determine the biological or surface-active properties of the compound. Understanding the relationship between the medium composition and the synthesis of the surfactin analog with the desired properties will allow the production of this compound for a specific purpose; in the future it will translate into lower production costs.

Author Contributions: Conceptualization, B.K.-P., G.K. and D.M.; methodology, B.K.-P., G.K. and D.M.; validation, B.K.-P., D.M. and J.M.D.-A.; investigation, B.K.-P., D.M., J.M.D.-A. and A.Z.; writing—original draft preparation, B. K-P. and J.M.D.-A.; writing—review and editing, G.K. and D.M.; supervision, G.K.; project administration, G.K. and D.M.; funding acquisition, G.K. All authors have read and agreed to the published version of the manuscript.

Funding: This study was supported by the Polish Minister of Science and Higher Education, under the program "Regional Initiative of Excellence" in 2019-2022 (Grant No. 008/RID/2018/19).

Institutional Review Board Statement: Not applicable.

Informed Consent Statement: Not applicable.

Data Availability Statement: The data presented in this study are available on request from the corresponding author.

Conflicts of Interest: The authors declare no conflict of interest.

Sample Availability: Samples of the compound are available from the corresponding author.

\section{References}

1. Nitschke, M.; Costa, S.G.V.A.O. Biosurfactants in food industry. Trends Food Sci. Technol. 2007, 18, 252-259. [CrossRef]

2. Vedaraman, N.; Venkatesh, N. Production of surfactin by Bacillus subtilis MTCC 2423 from waste frying oils. Braz. J. Chem. Eng. 2011, 28, 175-180. [CrossRef]

3. Vollenbroich, D.; Özel, M.; Vater, J.; Kamp, R.M.; Pauli, G. Mechanism of inactivation of enveloped viruses by the biosurfactant surfactin from Bacillus subtilis. Biologicals 1997, 25, 289-297. [CrossRef] [PubMed]

4. Seydlová, G.; Svobodová, J. Review of surfactin chemical properties and the potential biomedical applications. Cent. Eur. J. Med. 2008, 3, 123-133. [CrossRef]

5. de Faria, A.F.; Teodoro-Martinez, D.S.; De Oliveira Barbosa, G.N.; Vaz, B.G.; Silva, I.S.; Garcia, J.S.; Totola, M.R.; Eberlin, M.N.; Grossman, M.; Alves, O.L.; et al. Production and structural characterization of surfactin (C 14/Leu7) produced by Bacillus subtilis isolate LSFM-05 grown on raw glycerol from the biodiesel industry. Process Biochem. 2011, 46, 1951-1957. [CrossRef]

6. Campos, J.M.; Stamford, T.L.; Sarubbo, L.A.; de Luna, J.M.; Rufino, R.D.; Banat, I.M. Microbial biosurfactants as additives for food industries. Biotechnol. Prog. 2013, 29, 1097-1108. [CrossRef]

7. Willenbacher, J.; Zwick, M.; Mohr, T.; Schmid, F.; Syldatk, C.; Hausmann, R. Evaluation of different Bacillus strains in respect of their ability to produce surfactin in a model fermentation process with integrated foam fractionation. Appl. Microbiol. Biotechnol. 2014, 98, 9623-9632. [CrossRef] [PubMed]

8. Lima, T.A.; Etchegaray, A.; Machini, M.T. Design, synthesis and valued properties of surfactin oversimplifed analogues. Amino Acids 2020, 52, 25-33. [CrossRef]

9. Zhao, Y.; Yang, S.Z.; Mu, B.Z. Quantitative analyses of the isoforms of surfactin produced by Bacillus subtilis HSO 121 using GC-MS. Anal. Sci. 2012, 28, 789-793. [CrossRef]

10. Jajor, P.; Piłakowska-Pietras, D.; Krasowska, A.; Łukaszewicz, M. Surfactin analogues produced by Bacillus subtilis strains grown on rapeseed cake. J. Mol. Struct. 2016, 1126, 141-146. [CrossRef]

11. Meena, K.R.; Kanwar, S.S. Lipopeptides as the antifungal and antibacterial agents: Applications in food safety and therapeutics. BioMed Res. Int. 2015, 5, 1-9. [CrossRef]

12. Paraszkiewicz, K.; Bernat, P.; Kuśmierska, A.; Chojniak, J.; Płaza, G. Structural identification of lipopeptide biosurfactants produced by Bacillus subtilis strains grown on the media obtained from renewable natural resources. J. Environ. Manag. 2018, 209, 65-70. [CrossRef] [PubMed]

13. Cooper, D.G.; Macdonald, C.R.; Duff, S.J.B.; Kosaric, N. Enhanced production of surfactin from Bacillus subtilis by continuous product removal and metal cation additions. Appl. Env. Microbiol. 1981, 42, 408-412. [CrossRef] [PubMed]

14. Akpa, E.; Jacques, P.; Wathelet, B.; Paquot, M.; Fuchs, R.; Budzikiewicz, H.; Thonart, P. Influence of culture conditions on lipopeptide production by Bacillus subtilis. Appl. Biochem. Biotechnol. 2001, 9193, 551-561. [CrossRef]

15. Arima, K.; Kakinuma, A.; Tamura, G. Surfactin, a crystalline peptidelipid surfactant produced by Bacillus subtilis: Isolation, characterization and its inhibition of fibrin clot formation. Biochem. Biophys. Res. Commun. 1968, 31, 488-494. [CrossRef] 
16. Sandrin, C.; Peypoux, F.; Michel, G. Coproduction of surfactin and iturin A, lipopeptides with surfactant and antifungal properties, by Bacillus subtilis. Biotechnol. Appl. Biochem. 1990, 12, 370-375.

17. Davis, D.A.; Lynch, H.C.; Varley, J. The production of surfactin in batch culture by Bacillus subtilis ATCC 21332 is strongly influenced by the conditions of nitrogen metabolism. Enzym. Microb. Technol. 1999, 25, 322-329. [CrossRef]

18. Abushady, H.M.; Bashandy, A.S.; Aziz, N.H.; Ibrahim, H.M.M. Molecular Characterization of Bacillus subtilis surfactin producing strain and the factors affecting its production. Int. J. Agric. Biol. 2005, 7, 337-344.

19. Cheng, Y.H.; Zhang, N.; Han, J.C.; Chang, C.W.; Hsiao, F.S.; Yu, Y.H. Optimization of surfactin production from Bacillus subtilis in fermentation and its effects on Clostridium perfringens-induced necrotic enteritis and growth performance in broilers. J. Anim. Physiol. Anim. Nutr. 2018, 102, 1232-1244. [CrossRef]

20. Chen, W.C.; Juang, R.S.; Wei, Y.H. Applications of a lipopeptide biosurfactant, surfactin, produced by microorganisms. Biochem. Eng. J. 2015, 103, 158-169. [CrossRef]

21. Das, K.; Mukherjee, A.K. Comparison of lipopeptide biosurfactants production by Bacillus subtilis strains in submerged and solid state fermentation systems using a cheap carbon source: Some industrial applications of biosurfactants. Process Biochem. 2007, 2, 1191-1199. [CrossRef]

22. Gudiña, E.J.; Fernandes, E.C.; Rodrigues, A.I.; Teixeira, J.A.; Rodrigues, L.R. Biosurfactant production by Bacillus subtilis using corn steep liquor as culture medium. Front. Microbiol. 2015, 6. [CrossRef]

23. Hmidet, N.; Ben Ayed, H.; Jacques, P.; Nasri, M. Enhancement of surfactin and fengycin production by Bacillus mojavensis A21: Application for diesel biodegradation. BioMed Res. Int. 2017. [CrossRef] [PubMed]

24. Nitschke, M.; Pastore, G.M. Production and properties of a surfactant obtained from Bacillus subtilis grown on cassava wastewater. Bioresour. Technol. 2006, 97, 336-341. [CrossRef] [PubMed]

25. Singh, A.K.; Rautela, R.; Cameotra, S.S. Substrate dependent in vitro antifungal activity of Bacillus sp. strain AR2. Microb. Cell Factories 2014, 13, 67. [CrossRef] [PubMed]

26. Makkar, R.S.; Cameotra, S.S. Utilization of molasses for biosurfactant production by two Bacillus strains at thermophilic conditions. J. Am. Oil Chem. Soc. 1997, 74, 887-889. [CrossRef]

27. Ghribi, D.; Ellouze-Chaabouni, S. Enhancement of Bacillus subtilis lipopeptide biosurfactants production through optimization of medium composition and adequate control of aeration. Biotechnol. Res. Int. 2011, 653-654. [CrossRef] [PubMed]

28. Abdel-Mawgoud, A.M.; Aboulwafa, M.M.; Hassouna, N.A.-H. Characterization of surfactin produced by Bacillus subtilis Isolate BS5. Appl. Biochem. Biotechnol. 2008, 150, 289-303. [CrossRef]

29. Jacques, P. Surfactin and Other Lipopeptides from Bacillus spp. In Biosurfactants; Springer: Berlin/Heidelberg, Germany, 2011; Volume 20, pp. 57-91.

30. Shaligram, N.S.; Singhal, R.S. Surfactin-A review on biosynthesis, fermentation, purification and applications. Food Technol. Biotechnol. 2010, 48, 119-134.

31. Joshi, P.A.; Shekhawat, D.B. Screening and isolation of biosurfactant producing bacteria from petroleum contaminated soil. Eur. J. Exp. Biol. 2014, 4, 164-169.

32. Rane, A.N.; Baikar, V.V.; Ravi Kumar, V.; Deopurkar, R.L. Agro-industrial wastes for production of biosurfactant by Bacillus subtilis ANR 88 and its application in synthesis of silver and gold nanoparticles. Front. Microbiol. 2017, 8. [CrossRef]

33. Makkar, R.S.; Cameotra, S.S. An update on the use of unconventional substrates for biosurfactant production and their new applications. Appl. Microbiol. Biotechnol. 2002, 58, 428-434. [CrossRef] [PubMed]

34. Al-Bahry, S.N.; Al-Wahaibi, Y.M.; Elshafie, A.E.; Al-Bemani, A.S.; Joshi, S.J.; AlMakhmari, H.S.; Al-Sulaimani, H.S. Biosurfactant production by Bacillus subtilis B20 using date molasses and its possible application in enhanced oil recovery. Int. Biodeterior. Biodegrad. 2013, 8, 141-146. [CrossRef]

35. Zhu, Z.; Zhang, F.; Wei, Z.; Ran, W.; Shen, Q. The usage of rice straw as a major substrate for the production of surfactin by Bacillus amyloliquefaciens XZ-173 in solid-state fermentation. J. Environ. Manag. 2013, 127, 96-102. [CrossRef] [PubMed]

36. de Oliveira, D.W.F.; França, I.W.L.; Félix, A.K.N.; Martins, J.J.L.; Giro, M.E.A.; Melo, V.M.M.; Goncalves, L.R.B. Kinetic study of biosurfactant production by Bacillus subtilis LAMI005 grown in clarified cashew apple juice. Colloid Surf. B 2013, 101, 34-43. [CrossRef]

37. Bartal, A.; Vigneshwari, A.; Bóka, B.; Vörös, M.; Takács, I.; Kredics, L.; Manczinger, L.; Varga, M.; Vágvölgyi, C.; Szekeres, A. Effects of different cultivation parameters on the production of surfactin variants by a Bacillus subtilis strain. Molecules 2018, 23, 2675. [CrossRef]

38. Ing-Lung, S.; Chia-Yu, K.; Feng-Chia, H.; Suey-Sheng, K.; Chienyan, H. Use of surface response methodology to optimize culture conditions for iturin A production by Bacillus subtilis in solid-state fermentation. J. Chin. Inst. Chem. Eng. 2008, 39, 635-643. [CrossRef]

39. Mizumoto, S.; Hirai, M.; Shoda, M. Production of lipopeptide antibiotic iturin A using soybean curd residue cultivated with Bacillus subtilis in solid-state fermentation. Appl. Microbiol. Biotechnol. 2006, 72, 869-875. [CrossRef]

40. Liu, J.F.; Yang, J.; Yang, S.Z.; Ye, R.Q.; Mu, B.Z. Effects of different amino acids in culture media on surfactin variants produced by Bacillus subtilis TD7. Appl. Biochem. Biotechnol. 2012, 166, 2091-2100. [CrossRef]

41. Konsula, Z.; Liakopoulou-Kyriakides, M. Hydrolysis of starches by the action of an -amylase from Bacillus subtilis. Process Biochem. 2004, 39, 1745-1749. [CrossRef] 
42. Tavallaire, S.; Khomeiri, M.; Mousivand, M.; Maghsoudlou, Y.; Hashemi, M. Starches from different sources hydrolysis using a new thermo-tolerant amylase complex produced by Bacillus subtilis T41a: Characterization and efficiency evaluation. LWT 2019, 112, 108218. [CrossRef]

43. Clarke, K.G. 2-Microbiology. Bioprocess Engineering, An Introductory Engineering and Life Sciences Approach; Woodhead Publishing: Cambridge, UK, 2013; pp. 7-24.

44. Reissbrodt, R.; Beer, W.; Muller, R.; Claus, H. Characterization of casein peptones by HPLC profiles and microbiological growth parameters. Acta Biotechnologica 1995, 15, 223-232. [CrossRef]

45. Tofalo, R.; Suzzi, G. Yeasts. In The Encyclopedia of Food and Health, 1st ed.; Caballero, B., Finglas, P.M., Toldrá, F., Eds.; Academic Press: Oxford, UK, 2016; Volume 1, pp. 593-599. [CrossRef]

46. Heron, J.R. Some observations on commercial malt extracts. J. Inst. Brew. 1966, 72, 452-457. [CrossRef]

47. Pearson, A.M. MEAT/Extracts. In Encyclopedia of Food Sciences and Nutrition, 2nd ed.; Caballero, B., Ed.; Academic Press: London, UK, 2003; pp. 3812-3817.

48. Sen, R.; Swaminathan, T. Application of response-surface methodology to evaluate the optimum environmental conditions for the enhanced production of surfactin. Appl. Microbiol. Biotechnol. 1997, 47, 358-363. [CrossRef]

49. Yuan, L.; Zhang, S.; Peng, J.; Li, Y.; Yang, Q. Synthetic surfactin analogues have improved anti-PEDV properties. PLoS ONE 2019, 14, e0215227. [CrossRef]

50. Banat, I.M.; Satpute, S.K.; Cameotra, S.S.; Patil, R.; Nyayanit, N.V. Cost effective technologies and renewable substrates for biosurfactants' production. Front. Microbiol. 2014, 5, 697. [CrossRef]

51. Dzwonkowski, W. Evolution of potato production in Poland and the EU. Zeszyty Naukowe Szkoły Głównej Gospodarstwa Wiejskiego w Warszawie-Problemy Rolnictwa Światowego 2017, 17, 71-80. [CrossRef]

52. Sampaio, S.L.; Petropoulos, S.A.; Alexopoulos, A.; Heleno, S.A.; Santos-Buelga, C.; Barros, L.; Ferreira, I.C.F.R. Potato peels as sources of functional compounds for the food industry: A review. Trends Food Sci. Technol. 2020, 103, 118-129. [CrossRef]

53. Sharma, D.; Ansari, M.J.; Gupta, S.; Al Ghamdi, A.; Pruthi, P.; Pruthi, V. Structural characterization and antimicrobial activity of a biosurfactant obtained from Bacillus pumilus DSVP18 grown on potato peels. Jundishapur J. Microbiol. 2015, 8, e21257. [CrossRef] [PubMed]

54. Schieber, A.; Saldaña, M.D.A. Potato peels: A source of nutritionally and pharmacologically interesting compounds-A review. Food 2009, 23-29. [CrossRef]

55. Pande, V.; Patel, V.; Salunke, P.; Patel, U. Biosynthesis and development of novel method for commercial production of biosurfactant utilizing waste potato peels. Indian Drugs 2019, 56, 12.

56. Fox, S.L.; Bala, G.A. Production of surfactant from Bacillus subtilis ATCC 21332 using potato substrates. Bioresour. Technol. 2000, 75, 235-240. [CrossRef]

57. Mukherjee, S.; Das, P.; Sen, R. Towards commercial production of microbial surfactants. Trends Biotechnol. 2006, 24, 509-515. [CrossRef] [PubMed]

58. Makkar, R.S.; Cameotra, S.S.; Banat, I.M. Advances in utilization of renewable substrates for biosurfactant production. $A M B$ Express 2011, 1, 5. [CrossRef]

59. Ansari, F.A.; Hussain, S.; Ahmed, B.; Akhter, J.; Shoeb, E. Use of patato peel as cheap carbon source for the bacterial production of biosurfactants. Int. J. Biol. Res. 2014, 2, 27-31.

60. Koim-Puchowska, B.; Kłosowski, G.; Mikulski, D.; Menka, A. Evaluation of various methods of selection of B. subtilis strains capable of secreting surface-active compounds. PLoS ONE 2019, 14. [CrossRef] [PubMed]

61. Kulkarni, S.O.; Kanekar, P.P.; Jog, J.P.; Sarnaik, S.S.; Nilegaonkar, S.S. Production of copolymer, poly (hydroxybutyrate-cohydroxyvalerate) by Halomonas campisalis MCM B-1027 using agro-wastes. Int. J. Biol. Macromol. 2015, 72, 784-789. [CrossRef]

62. Walter, V.; Syldatk, C.; Hausmann, R. Screening concepts for the isolation of biosurfactant producing microorganisms. Biosurfactants 2010, 672, 1-13.

63. Ahmed, I.; Zia, M.A.; Iftikhar, T.; Iqbal, H.M.N. Characterization and detergent compatibility of purified protease produced from Aspergillus niger by utilizng of agro wastes. BioResources 2011, 6, 4505-4522. 